\title{
Monitoring of landfill gas emission rates: application of the static chamber approach to an Italian sanitary landfill site
}

\author{
B. Capaccioni ${ }^{1}$, C. Caramiello ${ }^{2}$, G. Corigliano ${ }^{3}$, S. de Rosa ${ }^{4}$, \\ F. Tatàno ${ }^{2} \& \mathrm{~A}$. Viscione ${ }^{2}$ \\ ${ }^{I}$ Departiment of Earth Sciences and Environmental Geology, \\ University of Bologna, Italy \\ ${ }^{2}$ DiGeoTeCA - Department of Geological Sciences, Chemical and \\ Environmental Technologies, University of Urbino "Carlo Bo", Italy \\ ${ }^{3}$ ASET Holding S.p.a., Fano, Italy \\ ${ }^{4}$ ASET S.p.a., Fano, Italy
}

\begin{abstract}
According to the European Landfill Directive 1999/31/EC and the related Italian Legislation "D.Lgs. No. 36/2003", monitoring and control procedures of landfill gas emissions, migration and external dispersions are clearly requested. A possible quantitative approach for field measurement and consequential evaluation of landfill gas emission rates $\left(\mathrm{CO}_{2}, \mathrm{CH}_{4}\right)$ consist of the static, non-stationary accumulation chamber technique. At the Italian level, a significant and recent situation of periodical biogas emission monitoring is represented by the sanitary landfill for non-hazardous waste of the "Fano" town district (Marche Region), whereas monitoring campaigns with the static chamber have been annually conducted during the last five years (2005-2009). This paper deals with some representative elaborations derivable from this multiyear monitoring experience.
\end{abstract}

Keywords: case-study, emission, landfill gas, measurement, static chamber.

\section{Introduction}

According to the new European waste Directive 2008/98/EC [1], waste disposal is still the conclusive option within the reorganised waste hierarchy. With 
specific respect to the atmospheric environment, landfills could generate significant environmental impacts both at local and global scales [2]. As far as particularly greenhouse gas emissions are concerned, landfill emissions are expected to constitute a principal source of the global anthropogenic methane production [3, 4]. According to the European landfill Directive 1999/31/EC [5], monitoring and control procedures of landfill gas emissions and migration are clearly requested. Additionally, the corresponding Italian legislation "D.Lgs. No. 36/2003" (as the national implementation of the landfill Directive) [6] expressly demands: 1) the monitoring of "collected" but also "diffuse" landfill gas emissions, including possible external gas dispersions; 2) the qualitative but also "quantitative" characterisation of landfill gas; 3) the identification of landfill gas migration; 4) the periodical monitoring of environmental media and emissions. A possible method for field measurements of landfill gas emission rates $\left(\right.$ as $\mathrm{g} \mathrm{m}^{-2} \mathrm{~d}^{-1}$ for $\mathrm{CO}_{2}$ and $\mathrm{CH}_{4}$ ) consists of the static, non-stationary (i.e., with instantaneous location on ground surface) accumulation chamber technique [4, 7-9]. At the Italian level, a significant and recent situation of periodical landfill gas emission monitoring is represented by the sanitary landfill for the non-hazardous waste of the Fano town district in the Marche Region, Adriatic Sea side, Central Italy (see Section 2.1). According to the methodological approach mentioned in Section 2.2 on gas emission rate measurements and consequential data elaboration and mapping with the static, non-stationary accumulation chamber method (Figure 1), specific monitoring campaigns have been annually conducted at the "Fano"

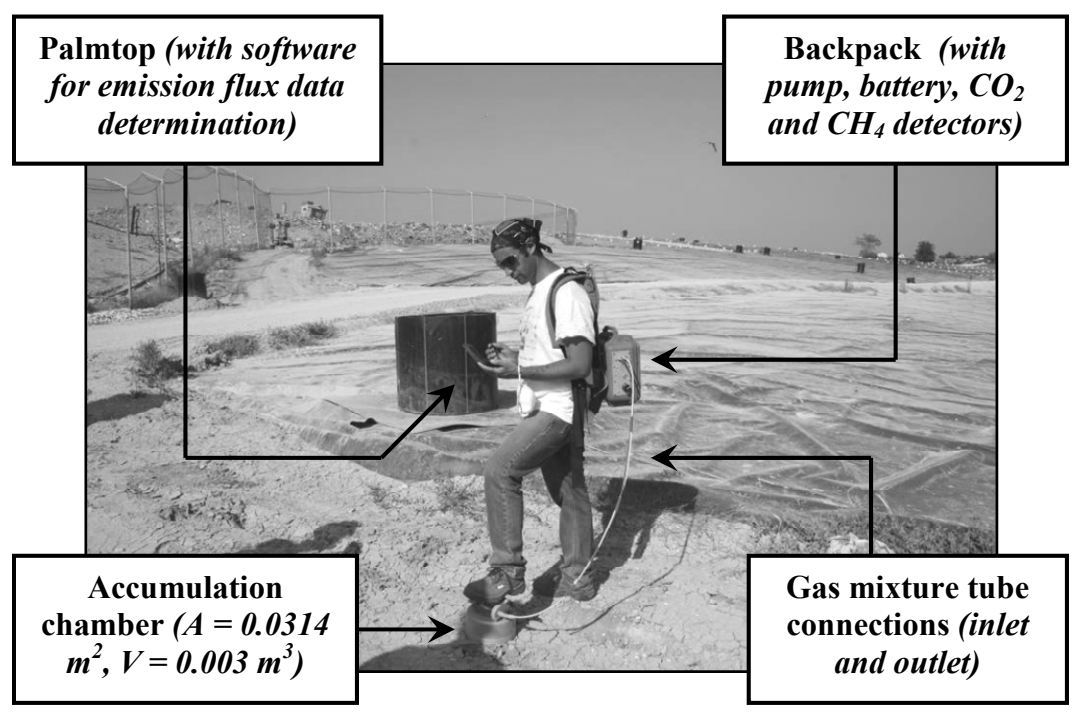

Figure 1: Exemplifying view of on-site measurement of $\mathrm{CO}_{2}$ and $\mathrm{CH}_{4}$ emission rates with the portable accumulation chamber instrument. The view refers to a measurement point on the border of "Fano" landfill Sub-section "2A" (2009 campaign: see Sections 2.1, 2.2). 
landfill site since 2005 [10, 11]. This paper summarises some experimental elaborations and indications (see Section 3) related to this multiyear monitoring study.

\section{Materials and methods}

\section{1 "Fano" case-study landfill}

The "Fano" sanitary landfill for non-hazardous waste, which is owned and operated by the "ASET" municipal multi-utility group, is comprised (2009 status) of the following, structural sections (Figure 2): 1) the oldest and inactive Section "1", which received in total about 1,4 million tons of municipal solid waste (MSW) during the period 1978-1996; 2) the subsequent and currently inactive Section "2", which received about 771,000 tons of MSW during the period 1996-2007; 3) the new, definable Section "3", which is currently active.

Section " 1 " is equipped with a final, composite cover system consisting of: 1) subbase, non-compacted clay layer; 2) compacted clay layer; 3) geotextilegeonet-geotextile drainage layer; 4) top soil. On the contrary, a temporary covering system, awaiting the evaluation of expected waste settlements, was installed during the year 2007 (after the corresponding monitoring campaign: see Section 2.2) on Section "2", with the following areal differentiations: 1) firstly, a clay layer for the overall Section; 2) secondly, an uppermost surface artificial sealing (1 mm HDPE) solely on a predominant areal portion (Sub-section "2A" in Figure 2), whilst the remaining portion (Sub-section "2B" in Figure 2) is without artificial sealing. In addition, during the year 2009 (prior to the corresponding monitoring campaign: see Section 2.2) an intermediate temporary road (with compacted soil) was realised inside Sub-section " $2 \mathrm{~A}$ " as a possible access to the active filling area (i.e., Section " 3 "). Consequently, the general

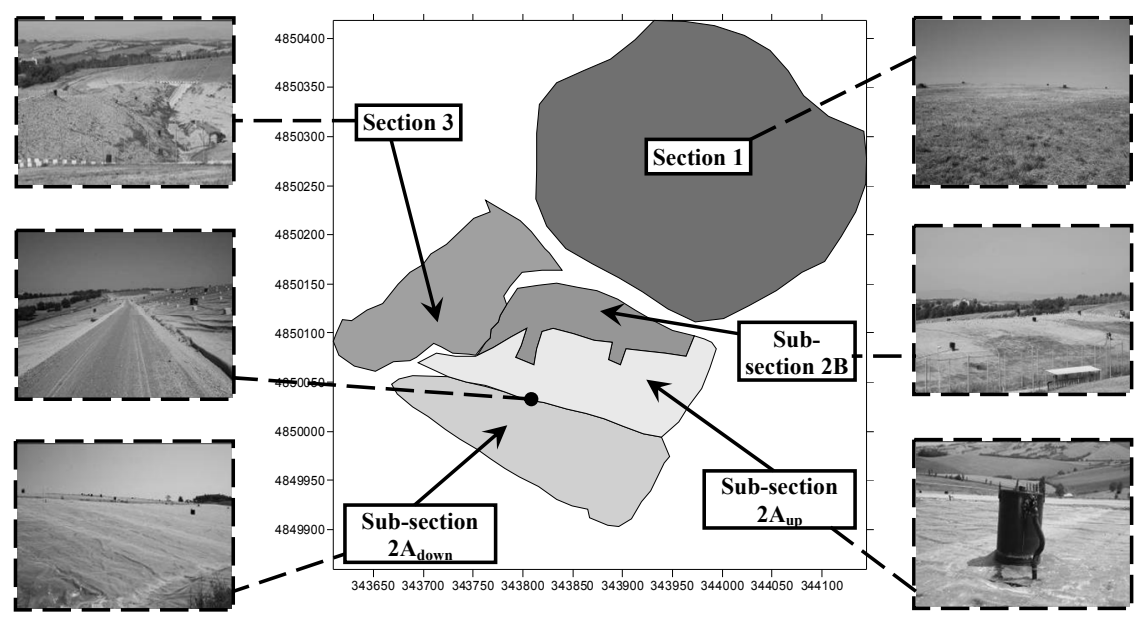

Figure 2: "Fano" case-study landfill, 2009 status: general layout. 


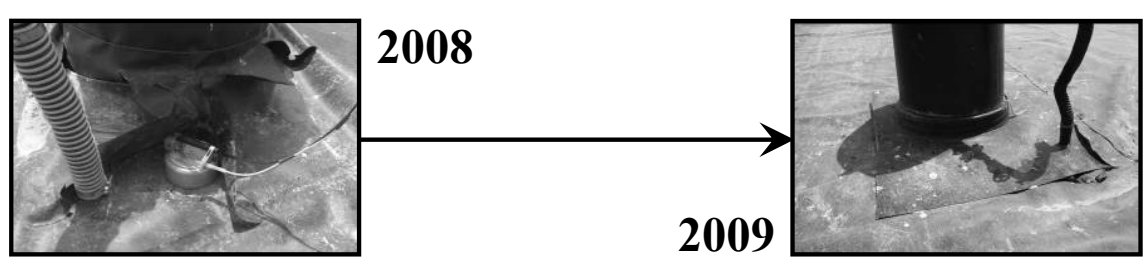

Figure 3: "Fano" case-study landfill, sub-section "2A": views of different conditions for the space surrounding landfill gas wells during the monitoring campaigns 2008 (left-hand side) and 2009 (right-hand side).

layout of Figure 2 shows also the further disaggregation of Sub-section " $2 \mathrm{~A}$ " in the two portions " $2 \mathrm{~A}_{\text {up }}$ " and " $2 \mathrm{~A}_{\text {down }}$ ", which are internally delimitated through the mentioned road. The Italian landfill legislation "D.Lgs. No. 36/2003" (see Section 1) gives the regulative possibility (in its Annex 1) of the installation of temporary covering systems on worked out landfill sections (prior to the final capping), in order to isolate landfilled waste with settlement in progress. Since 2007, landfill gas at "Fano" landfill site is collected through vertical wells and on-site converted to electricity. Regarding landfill gas wells specifically located in Sub-section "2A", some open spaces (i.e., not completely sealed: Figure 3, left-hand side) appeared around these wells at the time of carrying-out of the 2008 monitoring campaign (see Section 2.2); on the contrary, a completed sealing around all sub-section wells (Figure 3, right-hand side) was present at the time of carrying-out the last (2009) monitoring campaign (see Section 2.2).

\subsection{Monitoring campaigns and data elaborations}

The following monitoring campaigns were yearly carried out at the "Fano" sanitary landfill site, with a progressive, increasing number (no.) of measurement points (for $\mathrm{CO}_{2}, \mathrm{CH}_{4}$ emission rates in pairs): 1) May 2005 campaign, no. 102 measurement points; 2) June 2006 campaign, no. 232 measurements points; 3) June 2007 campaign, no. 240 measurement points; 4) July 2008 campaign, no. 297 measurements points; 5) July 2009 campaign, no. 312 measurement points. The procedures for on-site measurement with the adopted portable accumulation chamber device (shown in Figure 1 and developed by West System Srl, Italy), and consequential determination of the corresponding $\mathrm{CO}_{2}, \mathrm{CH}_{4}$ emission rates (as $\mathrm{g} \mathrm{m}^{-2} \mathrm{~d}^{-1}$ ) at each measurement point, are summarised in [9]. For the carriedout monitoring campaigns, areal $\mathrm{CO}_{2}, \mathrm{CH}_{4}$ emission maps were contoured separately for each "Fano" landfill section with Surfer ${ }^{\circledR}$ 8.0 software (Golden Software, Inc.), by using the interpolation technique "IDP, Inverse Distance to a Power" (or equivalently definable "IDW, Inverse Distance Weighting"), with the typical weighting power of 2 . The application of "IDW" for spatial interpolation of chamber flux measurements at landfill sites is documented in the international technical-scientific literature [12]. Further, Figure 4 schematises the calculation approach specifically adopted in this paper for the determination of the resulting 


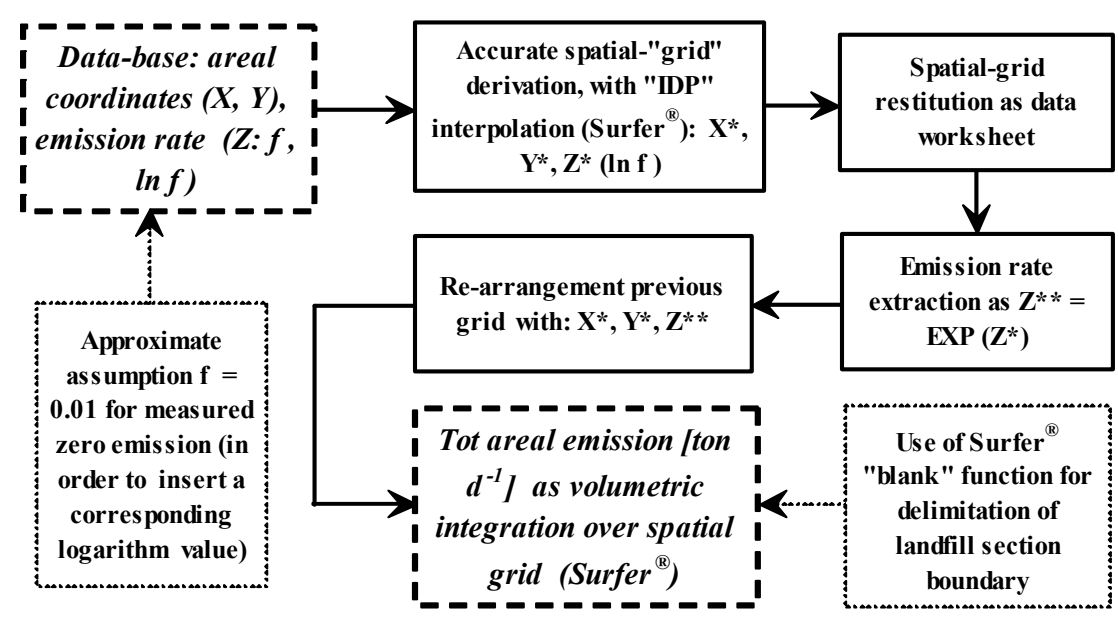

Figure 4: "Fano" case-study landfill, annual monitoring campaigns: procedure applied in this paper for the estimation of total $\mathrm{CO}_{2}, \mathrm{CH}_{4}$ areal emissions (as ton $\mathrm{d}^{-1}$ ) for individual landfill sections. Legend: $\varphi=\mathrm{CO}_{2}$ or $\mathrm{CH}_{4}$ emission rate $\left(\right.$ as $\mathrm{g} \mathrm{m}^{-2} \mathrm{~d}^{-1}$ ) at each measurement point.

total $\mathrm{CO}_{2}, \mathrm{CH}_{4}$ areal emissions (as ton $\mathrm{d}^{-1}$ ) during each carried-out monitoring campaign, individually for the different "Fano" landfill sections. Indeed, for Subsection " $2 \mathrm{~A}$ " (with temporary surface artificial sealing: see Section 2.1) two peculiar hypotheses were assumed for the approximate estimation of total daily emissions $\left(\mathrm{CO}_{2}, \mathrm{CH}_{4}\right)$ related to the 2008 and 2009 campaigns. Firstly referring to the 2008 monitoring campaign, due to the detection of considerable emission rates during the location of accumulation chamber in existing open spaces (i.e., not completely sealed) around landfill gas wells in Sub-section "2A" (Figure 3, left-hand side), an hypothetical "emission circular sector" (1 m width) was associated with each affected well. Regarding instead the last monitoring campaign (2009) with landfill gas emissions measured along the corresponding boundary of sub-section portions " $2 \mathrm{~A}_{\text {up }}$ " and " $2 \mathrm{~A}_{\mathrm{down}}$ " (see Figure 2 ), an overall "boundary emission strip" (1 m width) was considered, including the internal temporary access road.

\section{Summary of results and discussion}

\subsection{Statistical analysis of emission rate data sets}

Table $1\left(\mathrm{CO}_{2}\right)$ and Table $2\left(\mathrm{CH}_{4}\right)$ contain the resulting values of commonly used statistical measures for all experimental emission rate data sets. As a whole, $\mathrm{CO}_{2}$ emission rates at "Fano" landfill (Table 1) ranged from 0.0 to about 13,100 $\mathrm{g} \mathrm{m}^{-2}$ $\mathrm{d}^{-1}$. Indeed, this overall experimental range is limited in comparison with the larger range $\left(0.0->40,000 \mathrm{~g} \mathrm{CO}_{2} \mathrm{~m}^{-2} \mathrm{~d}^{-1}\right)$ resulting on the whole for some monitored (active and inactive) landfills in the provincial territory of Arezzo 
(Tuscany Region, Italy) [9]. According to Table 2, $\mathrm{CH}_{4}$ emission rates at "Fano" landfill varied on the whole from 0.0 to about $3,800 \mathrm{~g} \mathrm{~m}^{-2} \mathrm{~d}^{-1}$. A possible range for landfill $\mathrm{CH}_{4}$ emissions from 0.0002 to $>4,000 \mathrm{~g} \mathrm{~m}^{-2} \mathrm{~d}^{-1}$ is reported in [13]. The CV (Coefficient of Variation) values in Table 1 and Table 2 indicate the

Table 1: "Fano" case-study landfill: statistical measures for the carried-out $\mathrm{CO}_{2}$ emission rate $(\varphi)$ monitoring campaigns. Legend: $\mathrm{SD}=$ Standard Deviation; $\mathrm{CV}=$ Coefficient of Variation.

\begin{tabular}{|c|c|c|c|c|c|c|c|}
\hline \multicolumn{2}{|r|}{ Campaign } & $\begin{array}{c}\text { No. of } \\
\text { data }\end{array}$ & $\begin{array}{c}\text { Mean } \varphi \\
{\left[\mathrm{g} \mathrm{m}^{-2} \mathrm{~d}^{-1}\right]}\end{array}$ & $\begin{array}{c}\text { SD } \\
{\left[\mathrm{g} \mathrm{m}^{-2} \mathrm{~d}^{-1}\right]}\end{array}$ & $\begin{array}{l}\mathrm{CV} \\
{[\%]}\end{array}$ & $\begin{array}{c}\operatorname{Min} \varphi \\
{\left[\mathbf{g ~ m}^{-2} \mathbf{d}^{-1}\right]}\end{array}$ & $\begin{array}{c}\operatorname{Max} \varphi \\
{\left[\mathrm{g} \mathrm{m}^{-2} \mathrm{~d}^{-1}\right]}\end{array}$ \\
\hline \multirow{2}{*}{ 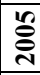 } & Section "1" & 45 & 8.69 & 26.98 & 310.5 & 0.10 & 180.96 \\
\hline & Section "2" & 57 & 353.47 & $1,199.67$ & 339.4 & 0.14 & $8,832.54$ \\
\hline \multirow{3}{*}{ 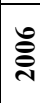 } & Section "1" & 79 & 7.37 & 11.77 & 159.7 & 0.00 & 78.53 \\
\hline & Section "2" & 103 & $303.60^{\circ}$ & $1,180.00$ & 388.7 & 0.00 & $9,862.70$ \\
\hline & External belt & 50 & 2.97 & 13.03 & $438.7^{-}$ & 0.00 & 92.60 \\
\hline \multirow{3}{*}{ ฮั } & Section "1" & 45 & 63.23 & 127.99 & 202.4 & 0.00 & 713.24 \\
\hline & Section "2" & 180 & 106.90 & 474.16 & 443.6 & 0.00 & $4,633.05$ \\
\hline & External belt & 15 & 45.77 & 69.85 & 152.6 & 0.00 & 263.11 \\
\hline \multirow{5}{*}{ 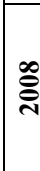 } & Section "1" & 78 & 43.36 & 285.04 & 657.4 & 0.14 & $2,518.80$ \\
\hline & Sub-section “2A, & 78 & 803.91 & $2,484.88$ & 309.1 & 0.00 & $13,106.74$ \\
\hline & Sub-section “2B", & 31 & 283.54 & 960.85 & 338.9 & 0.14 & $4,835.06$ \\
\hline & Section "3" & $81^{\circ}$ & 646.96 & $1,747.12$ & 270.0 & 0.00 & $12,166.39$ \\
\hline & External belt & 29 & 48.66 & 56.12 & $115.3^{-1}$ & 0.99 & 263.09 \\
\hline \multirow{5}{*}{ ঠे } & Section "1". & 80. & 41.39 & 173.40 & 418.9 & 0.16 & $1,476.78$ \\
\hline & Sub-section “2A, & 49 & 92.44 & 432.96 & 468.4 & 0.00 & $3,017.47$ \\
\hline & Sub-section “2B", & 50 & 34.15 & 110.52 & 323.6 & 0.00 & 745.80 \\
\hline & Section “3" & 92. & 358.38 & 938.83 & 262.0 & 0.00 & $5,724.53$ \\
\hline & External belt & 41 & 23.85 & 56.28 & 236.0 & 0.00 & 347.97 \\
\hline
\end{tabular}

Table 2: "Fano" case-study landfill: statistical measures for the carried-out $\mathrm{CH}_{4}$ emission rate $(\varphi)$ monitoring campaigns. Legend: see Table 1.

\begin{tabular}{|c|c|c|c|c|c|c|c|}
\hline \multicolumn{2}{|r|}{ Campaign } & $\begin{array}{c}\text { No. of } \\
\text { data }\end{array}$ & $\begin{array}{c}\operatorname{Mean} \varphi \\
{\left[\mathrm{g} \mathrm{m}^{-2} \mathrm{~d}^{-1}\right]}\end{array}$ & $\begin{array}{c}\text { SD } \\
{\left[\mathrm{g} \mathrm{m}^{-2} \mathbf{d}^{-1}\right]}\end{array}$ & $\begin{array}{l}\mathrm{CV} \\
{[\%]}\end{array}$ & $\begin{array}{c}\operatorname{Min} \varphi \\
{\left[\mathbf{g ~ m}^{-2} \mathbf{d}^{-1}\right]}\end{array}$ & $\begin{array}{c}\operatorname{Max} \varphi \\
{\left[\mathrm{g} \mathrm{m}^{-2} \mathrm{~d}^{-1}\right]}\end{array}$ \\
\hline \multirow{2}{*}{ 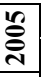 } & Section "1" & 45 & 2.13 & 11.73 & 550.7 & 0.01 & 78.51 \\
\hline & Section "2" & $57^{-}$ & 59.88 & 169.22 & 282.6 & 0.00 & $1,075.65$ \\
\hline \multirow{3}{*}{ હั่ } & Section "1" & 79 & 0.30 & 0.73 & 243.3 & 0.00 & 3.43 \\
\hline & Section "2" & 103 & 69.95 & 357.50 & 511.1 & 0.00 & $2,822.00$ \\
\hline & External belt & $50^{-}$ & $1.49^{-}$ & $7.40^{-}$ & 496.6 & 0.00 & 52.11 \\
\hline \multirow{3}{*}{ હે } & Section "1" & 45 & 3.19 & 1.86 & 58.3 & 0.00 & 6.80 \\
\hline & Section " $2 "$ & 180 & 16.92 & 89.66 & 529.9 & 0.00 & 909.76 \\
\hline & External belt & $15^{-}$ & $2.87^{-}$ & 1.66 & 57.8 & 0.00 & $5.29^{-}$ \\
\hline \multirow{5}{*}{ ڤ્̀ે } & Section "1" & 78 & 7.50 & 7.18 & 95.7 & 0.05 & 47.28 \\
\hline & Sub-section " $2 \mathrm{~A}$ " & 78 & $170.40^{\circ}$ & 586.67 & 344.3 & 0.00 & $3,798.02$ \\
\hline & Sub-section "2B" & 31 & 52.47 & 158.65 & 302.4 & 0.44 & 761.10 \\
\hline & Section "3" & 81 & $146.99^{-}$ & 438.66 & $2984^{\circ}$ & 0.00 & $2,642.65$ \\
\hline & External belt & 29 & $6.01^{\circ}$ & 6.93 & $115.3^{\circ}$ & 0.00 & 28.96 \\
\hline \multirow{5}{*}{ હે̊ } & Section "1". & 80. & 36.04 & 277.10 & 768.9 & 0.00 & $2,483.34$ \\
\hline & Sub-section " $2 \mathrm{~A}$ " & 49 & 17.11 & 43.76 & 255.8 & $0.00^{\circ}$ & 227.14 \\
\hline & Sub-section "2B" & 50 & 9.47 & 13.83 & 146.0 & 1.06 & 89.50 \\
\hline & Section "3" & 92 & 91.95 & 259.16 & 281.8 & 0.00 & $1,808.54$ \\
\hline & External belt & 41 & 20.98 & 110.75 & 527.9 & 0.00 & 712.65 \\
\hline
\end{tabular}




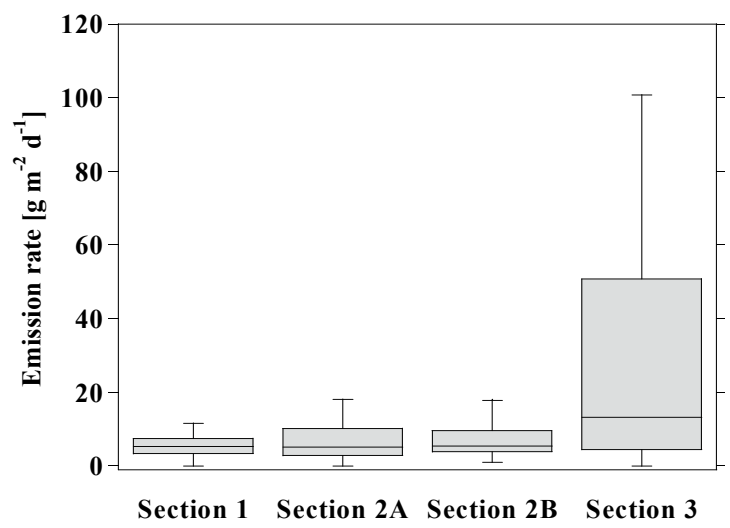

Figure 5: "Fano" case-study landfill, 2009 monitoring campaign: exemplifying "box-plots" for $\mathrm{CH}_{4}$ emission rate distributions.

high spatial variability of measured point-specific rates [8, 9]. Generally for all sections and monitoring campaigns at "Fano" case-study landfill, log-normal distribution was a better function (as compared solely with the normal one) describing approximately the distribution of the emission rate data sets [10]. Thus, this circumstance has justified the logarithm-based approach of Figure 4.

Notably, in the new Section "3", which is only recently active at "Fano" landfill (see Section 2.1), the resulting $\mathrm{CO}_{2}, \mathrm{CH}_{4}$ mean emission rates during the last monitoring campaigns $(2008,2009)$ were comparatively high. In fact, Section " 3 " is characterised in Tables 1 and 2 by the highest $\mathrm{CO}_{2}, \mathrm{CH}_{4}$ mean emission rates for the 2009 campaign in comparison with the remaining landfill sections, whilst for the 2008 campaign Section " 3 " is at second position considering the $\mathrm{CO}_{2}, \mathrm{CH}_{4}$ mean emission rates in decreasing order. As indicative of a graphical approach for a further statistical analysis of the emission rate data sets, Figure 5 exemplifies the resulting "box-plots" related to the $\mathrm{CH}_{4}$ emission rate distributions of the 2009 monitoring campaign for each "Fano" landfill section. Typically, a "box-plot" (or "Tukey diagram") represents the lower, median and upper quartiles, as well as two lines ("whiskers") for the individuation of possible "outliers". Figure 5 shows that both the median and mainly the variability of $\mathrm{CH}_{4}$ emission rate distribution are greater for Section " 3 " in comparison with the remaining landfill sections. The corresponding no. of outliers for the $\mathrm{CH}_{4}$ emission rate distributions during the last monitoring campaign were, respectively: 1$)$ no. $2(2.5 \%$ of the total section data) for Section " 1 "; 2) no. 7 (14\% of the total sub-section data) for Sub-section " 2 A"; 3 ) no. 5 ( $10 \%$ of the total sub-section data) for Sub-section " $2 \mathrm{~B}$ "; 4$)$ no. $11(12 \%$ of the total section data) for Section " 3 ". Interestingly, 9 measurement points out of the total (11) $\mathrm{CH}_{4}$ emission rate outliers for Section "3" (2009 monitoring campaign) were located along the north/north-western slopes and the internal south border. 
Table 3: "Fano" case-study landfill: resulting $\mathrm{CO}_{2}, \mathrm{CH}_{4}$ areal emissions during each annual monitoring campaign, according to the calculation procedures of Figure 4 and Section 2.2.

\begin{tabular}{|c|c|c|c|c|c|}
\hline \multirow{2}{*}{$\begin{array}{c}\text { Landfill Section (see } \\
\text { Figure 2) }\end{array}$} & 2005 & 2006 & 2007 & 2008 & 2009 \\
\hline & \multicolumn{5}{|c|}{$\mathrm{CO}_{2}\left[\operatorname{ton} d^{-1}\right]$} \\
\hline Section "1" & 0.17 & 0.17 & 1.76 & 0.66 & 0.87 \\
\hline Section "2" & 5.21 & 3.25 & 1.50 & & \\
\hline Sub-section " $2 \mathrm{~A}$ " & - & $=$ & - & 0.36 & 0.11 \\
\hline Sub-section " $2 \mathrm{~B}$ " & - & $=$ & $=$ & 0.32 & 0.08 \\
\hline Section "3" & - & - & - & 1.45 & 1.82 \\
\hline External belt & - & 0.27 & 0.75 & 0.45 & 0.15 \\
\hline \multirow[t]{2}{*}{ Total } & 5.38 & 3.69 & 4.01 & 3.24 & 3.03 \\
\hline & \multicolumn{5}{|c|}{$\mathrm{CH}_{4}\left[\right.$ ton $\left.d^{-1}\right]$} \\
\hline Section "1" & 0.005 & 0.004 & 0.16 & 0.42 & 0.41 \\
\hline Section "2" & 0.52 & 0.25 & 0.18 & & \\
\hline Sub-section " $2 \mathrm{~A}$ " & - & $=$ & - & 0.08 & 0.02 \\
\hline Sub-section " $2 \mathrm{~B}$ " & - & - & - & 0.12 & 0.06 \\
\hline Section "3" & - & - & - & 0.33 & 0.43 \\
\hline External belt & - & 0.02 & 0.07 & 0.05 & 0.11 \\
\hline Total & 0.53 & 0.27 & 0.41 & 1.00 & 1.03 \\
\hline
\end{tabular}

\subsection{Total areal emissions and approximate volumetric gas balance}

In accordance with the applied procedure of Figure 4 and the specific assumptions for Sub-section "2A" (see Section 2.2), Table 3 reports the resulting total $\mathrm{CO}_{2}, \mathrm{CH}_{4}$ areal emissions (as ton $\mathrm{d}^{-1}$ ) during each annual monitoring campaign, separately for "Fano" landfill sections.

For a comparative evaluation of data in Table 3 , at least the following considerations can be pointed out. Firstly, the reduction of $\mathrm{CO}_{2}, \mathrm{CH}_{4}$ total emissions in Section " 2 " during the 2006 campaign, as compared with the first campaign (2005), could likely be explained by both operational measures (soil stratum covering) and meteorological conditions (rain events before and during the 2006 monitoring days with consequential wet saturation of the soil cover, thus probably obstructing the diffuse emission of landfill gas). Secondly, the mentioned activation of the landfill gas extraction system with conversion to electricity, at the end of year 2006 (see Section 2.1), could have positively influenced the containment of $\mathrm{CO}_{2}, \mathrm{CH}_{4}$ areal emissions in Section " 2 " during the 2007 campaign as compared with the previous campaigns. Differently, the concurrent 2007 emission increase for both $\mathrm{CO}_{2}$ and $\mathrm{CH}_{4}$ in Section " 1 " could likely be connected with the specific meteorological conditions during the 2007 monitoring days (dry period, with consequential diffuse presence of soil cracks). Lastly, the combined effect of implementing the temporary artificial sealing in Sub-section " $2 \mathrm{~A}$ " (during summer 2007, after carrying-out the related monitoring campaign: see Section 2.1), with concurrent opening of the new active filling area (Section "3") without horizontal discontinuity (see Figure 2), could likely be shown by the resulting preferential route - during the 2008, 2009 campaigns - of landfill gas emission concentration through the open spaces around wells in Subsection "2A" (solely for the 2008 campaign: see Figure 3), the remaining Sub-section "2B", and mainly the adjacent new Section "3". 
In order to roughly estimate the collection efficiency of landfill gas at "Fano" case-study landfill, Table 4 reports an approximate volumetric balance related to the monitoring campaigns 2007-2009. The elaboration of Table 4 is based on the following assumptions: 1) the landfill gas balance is simplified only with the contributions of recovered gas and emitted gas, thus neglecting the possible influence $[4,12]$ of further components as gas internally stored, $\mathrm{CH}_{4}$ oxidised, and additional gas escape and migration (apart from the limited external belts considered during each monitoring campaign: see Tables 1,2);2) the component of landfill gas emission is based on the resulting data of "Total"-named rows in Table 3, under the calculation hypothesis of gas volumetric composition only with $\mathrm{CO}_{2}$ and $\left.\mathrm{CH}_{4} ; 3\right)$ the component of landfill gas recovery is directly calculated from available gas flow rate measurements at "Fano" landfill, considering both temporal options of the average condition during the monitoring campaigns days or alternately the average monthly condition (with reference to the occurrence month for each monitoring campaign). In spite of some slight annual reductions, the recovery efficiencies in Table 4 appear quite consistent. A certain reliability of the recovery efficiencies of Table 4 is derivable from the following considerations: 1) at a site-specific level, the design criterion of the mentioned gas collection and energy recovery system at "Fano" landfill properly assumed a recovery efficiency respectively of $85 \%$ for Section "1" and $80 \%$ for Section "2" (see Figure 2), with a consequential average planning value of $82.5 \%$; 2) at a general level, although for those landfills that collect landfill gas the collection efficiencies reported in the technical-scientific literature vary widely [14], recently it has been shown that well designed and operated landfills can achieve landfill gas recoveries particularly high $[4,12]$.

\subsection{Exemplification of areal emission rate maps}

By way of example, Figure 6 contains the resulting areal $\mathrm{CH}_{4}$ emission rate maps disaggregated for landfill sections (see Figure 2), with reference to the 2009 monitoring campaign at "Fano" case-study landfill. Concerning the oldest and inactive Section "1", the corresponding map (Figure 6, left-up) shows a

Table 4: "Fano" case-study landfill, 2007-2009 monitoring campaigns: approximate landfill gas balance. Legend: $L F G=$ landfill gas.

\begin{tabular}{|c|c|c|c|c|c|}
\hline Campaign & $\begin{array}{c}\text { LFG } \\
\text { Recovery } \\
{\left[\mathbf{N m}^{\mathbf{3}} \mathbf{h}^{-1}\right]}\end{array}$ & $\begin{array}{c}\text { LFG } \\
\text { Emission } \\
{\left[\mathbf{N m}^{\mathbf{3}} \mathbf{h}^{-1}\right]}\end{array}$ & $\begin{array}{c}\text { LFG } \\
\text { Recovery + } \\
\text { Emission } \\
{\left[\mathbf{N m}^{\mathbf{3}} \mathbf{h}^{-1}\right]}\end{array}$ & \% Recovery & \% Emission \\
\hline \multicolumn{7}{|c|}{ average LFG recovery during the occurrence month of monitoring campaign } \\
\hline $\mathbf{2 0 0 7}$ & 618.1 & 109.0 & 727.1 & 85 & 15 \\
\hline $\mathbf{2 0 0 8}$ & 604.9 & 127.2 & 732.1 & 83 & 17 \\
\hline $\mathbf{2 0 0 9}$ & 517.8 & 124.4 & 642.2 & 81 & 19 \\
\hline \multicolumn{7}{|c|}{ average LFG recovery during the monitoring campaign days } \\
\hline $\mathbf{2 0 0 7}$ & 625.1 & 109.0 & 734.1 & 85 & 15 \\
\hline $\mathbf{2 0 0 8}$ & 599.7 & 127.2 & 726.9 & 83 & 17 \\
\hline $\mathbf{2 0 0 9}$ & 599.2 & 124.4 & 723.6 & 83 & 17 \\
\hline
\end{tabular}




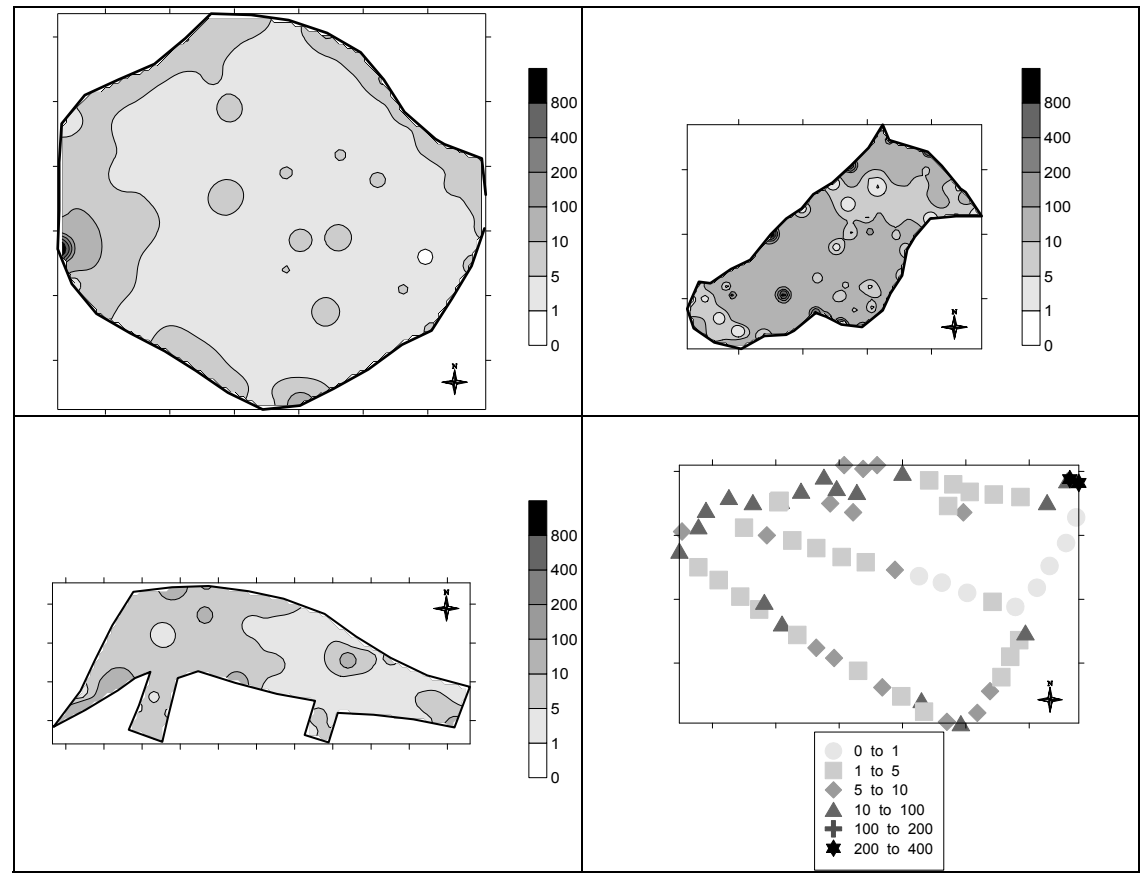

Figure 6: "Fano" case-study landfill, 2009 monitoring campaign: areal maps of $\mathrm{CH}_{4}$ emission rates $\left[\mathrm{g} \mathrm{m}^{-2} \mathrm{~d}^{-1}\right.$ ], disaggregated for landfill sections (Left-up, Section "1"; left-down, Sub-section "2B"; right-up, Section "3"; right-down, Sub-section " $2 \mathrm{~A}$ " as classification map).

geometrical landfill gas dispersion classifiable as internal and diffuse (in accordance with the geometrical classification proposed in [9]), in combination with internal, lateral dispersions along the north-eastern and west/north-western borders. In Sub-section "2B" (without artificial sealing: see Section 2.1), internal and diffuse $\mathrm{CH}_{4}$ dispersions were revealed (Figure 6, left-down); notably, the areal zone of comparatively higher emissions regards the sub-section western portion, which is properly adjacent to the new and active Section " 3 " (see Figure 2). Referring to Sub-section " $2 \mathrm{~A}$ " (with temporary artificial sealing: see Section 2.1), the classification map of Figure 6 (right-down) comparatively shows a certain presence of relatively higher boundary $\mathrm{CH}_{4}$ emission rates along the north-western border of adjacency to Sub-section " $2 \mathrm{~B}$ " and Section " 3 "; moreover, the highest $\mathrm{CH}_{4}$ emission rates at the sub-section north-eastern corner were connected with some existing open splits in the artificial sealing. Interestingly, for the new and recently active Section " 3 " the corresponding map in Figure 6 (right-up) shows unexpected, relatively significant and internally diffused $\mathrm{CH}_{4}$ emissions, in combination with some localised boundary emissions along the north/north-western slopes and the south internal border. 
Table 5: "Fano" case-study landfill, 2009 monitoring campaign: percentages of distribution of the experimental $\mathrm{CH}_{4}\left[\mathrm{~L} \mathrm{~m}^{-2} \mathrm{~d}^{-1}\right]$, $\mathrm{CO}_{2}\left[\mathrm{~L} \mathrm{~m} \mathrm{~m}^{-2} \mathrm{~d}^{-1}\right]$ volumetric emission rates (in pairs) within appropriate $\mathrm{CH}_{4} / \mathrm{CO}_{2}$ ranges, for each landfill section.

\begin{tabular}{|c|c|c|c|c|}
\hline $\mathrm{CH}_{4} / \mathrm{CO}_{2}$ ranges & Section "1" & $\begin{array}{c}\text { Sub-section } \\
\text { " } 2 \mathrm{~A} "\end{array}$ & $\begin{array}{c}\text { Sub-section } \\
\text { "2B" }\end{array}$ & Section "3" \\
\hline $\mathrm{CH}_{4} / \mathrm{CO}_{2}<1$ & $33 \%$ & $42 \%$ & $22 \%$ & $68 \%$ \\
\hline $\mathrm{CH}_{4} / \mathrm{CO}_{2}>1$ & $67 \%$ & $58 \%$ & $78 \%$ & $32 \%$ \\
\hline $\mathrm{CH}_{4} / \mathrm{CO}_{2}<0.6$ & $19 \%$ & $22 \%$ & $12 \%$ & $51 \%$ \\
\hline $0.6<\mathrm{CH}_{4} / \mathrm{CO}_{2}<1$ & $22 \%$ & $22 \%$ & $16 \%$ & $23 \%$ \\
\hline $\mathrm{CH}_{4} / \mathrm{CO}_{2}>1.2$ & $59 \%$ & $56 \%$ & $72 \%$ & $26 \%$ \\
\hline
\end{tabular}
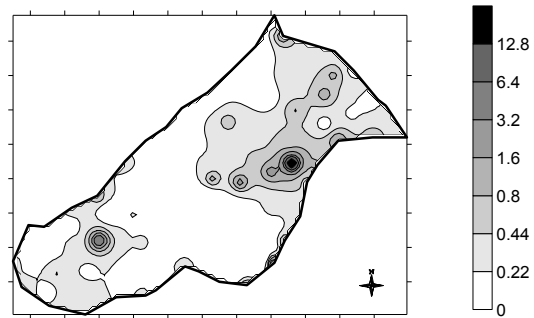

Figure 7: "Fano" case-study landfill, 2009 monitoring campaign: contoured map of $\mathrm{CH}_{4} / \mathrm{CO}_{2}$ weight-emission ratio for Section "3".

\subsection{Selective characterisation of $\mathrm{CH}_{4}, \mathrm{CO}_{2}$ emission rates}

For the monitoring data sets of each landfill section, expressed as volumetric $\mathrm{CH}_{4}, \mathrm{CO}_{2}$ emission rates in pairs $\left[\mathrm{L} \mathrm{m}^{-2} \mathrm{~d}^{-1}\right]$, the following volumetric $\mathrm{CH}_{4} / \mathrm{CO}_{2}$ conditions could be representatively considered [10]: 1) $\mathrm{CH}_{4} / \mathrm{CO}_{2}=1$, which defines two complementary measurement data ranges, respectively with dominant $\mathrm{CH}_{4}$ (i.e., $\mathrm{CH}_{4} / \mathrm{CO}_{2}>1$ ) or dominant $\mathrm{CO}_{2}$ (i.e., $\mathrm{CH}_{4} / \mathrm{CO}_{2}<1$ ); 2) $\mathrm{CH}_{4} / \mathrm{CO}_{2}=0.6$, as indicative of a typical landfill gas composition during the unstable methanogenic phase (i.e., $\mathrm{CH}_{4} 38 \%$ vol., $\mathrm{CO}_{2} 60 \%$ vol.); 3) $\mathrm{CH}_{4} / \mathrm{CO}_{2}=$ 1.2 , as indicative of a typical landfill gas composition during the subsequent stable methanogenic phase (i.e., $\mathrm{CH}_{4} 55 \%$ vol., $\mathrm{CO}_{2} 45 \%$ vol.). Referring to the 2009 monitoring campaign, Table 5 reports (for each "Fano" landfill section) the resulting percentages of distribution of experimental $\mathrm{CH}_{4}\left[\mathrm{~L} \mathrm{~m}^{-2} \mathrm{~d}^{-1}\right], \mathrm{CO}_{2}\left[\mathrm{~L} \mathrm{~m}^{-2}\right.$ $\mathrm{d}^{-1}$ ] volumetric rates in pairs within the following ranges: 1) the complementary ranges $\mathrm{CH}_{4} / \mathrm{CO}_{2}<1, \mathrm{CH}_{4} / \mathrm{CO}_{2}>1 ; 2$ ) a more detailed disaggregation in the complementary ranges $\mathrm{CH}_{4} / \mathrm{CO}_{2}<0.6,0.6<\mathrm{CH}_{4} / \mathrm{CO}_{2}<1.2, \mathrm{CH}_{4} / \mathrm{CO}_{2}>1.2$.

With regard to the recently active landfill Section " 3 " (see Section 2.1), the data in Table 5 show the following aspects: 1) the percentage of experimental $\mathrm{CH}_{4}, \mathrm{CO}_{2}$ volumetric emission rates (in pairs) resulting in the range $\mathrm{CH}_{4} / \mathrm{CO}_{2}>1$ is not negligible $(32 \%) ; 2)$ further, an unexpected, significant percentage $(23+$ $26=49 \%$ ) of experimental $\mathrm{CH}_{4}, \mathrm{CO}_{2}$ volumetric emission rates (in pairs) is globally located in the range defined by the lower limit of typical unstable methanogenic conditions (i.e., $\mathrm{CH}_{4} / \mathrm{CO}_{2}>0.6$ ). As a complementary elaboration, Figure 7 shows the contoured map for the $\mathrm{CH}_{4} / \mathrm{CO}_{2}$ weight-flux ratio resulting at 
"Fano" landfill Section "3" during the last monitoring campaign (2009). In Figure 7 , the threshold levels of 0.22 and $0.44 \mathrm{CH}_{4} / \mathrm{CO}_{2}$ weight-emission ratio can be assumed equivalent respectively to the mentioned levels of 0.6 and 1.2 $\mathrm{CH}_{4} / \mathrm{CO}_{2}$ volumetric-emission ratio. Consequently, also the areal map of Figure 7 confirms the presence in Section "3" of non-negligible spatial portions with gas emissions having characteristics comparable with typical methanogenic (unstable and stable) conditions (i.e., $\mathrm{CH}_{4} / \mathrm{CO}_{2}$ weight-emission ratio $>0.22$ ).

\subsection{Specific areal emissions for the whole landfill}

Referring to the whole "Fano" landfill extension, in combination with the daily emissions in the "Total"-named rows of Table 3, Figure 8 shows the resulting specific $\mathrm{CO}_{2}$ and $\mathrm{CH}_{4}$ areal emissions (as $\mathrm{t} \mathrm{ha} \mathrm{h}^{-1} \mathrm{~d}^{-1}$ ) during the carried-out monitoring campaigns. For the last campaigns 2008 and 2009, the specific $\mathrm{CO}_{2}$ areal emissions are below the upper limit $\left(30 \mathrm{~g} \mathrm{CO}_{2} \mathrm{~m}^{-2} \mathrm{~d}^{-1}\right)$ of natural emission from mature soil $[9,10]$, whilst the specific $\mathrm{CH}_{4}$ areal emissions are only at the lower limit of the range $0.1-1.0 \mathrm{t} \mathrm{CH}_{4} \mathrm{ha}^{-1} \mathrm{~d}^{-1}$ indicatively reported in [4].

\section{Conclusions}

According to the multiyear application at "Fano" sanitary landfill, the static, nonstationary chamber methodology can be considered as a possible, periodical and reliable approach in response to the EU and Italian requirements on monitoring, evaluation and control of landfill gas emissions and migration. Further, some elaborations (see Sections 3.1, 3.2, 3.3, 3.4) of the measured gas emission data at "Fano" case-study landfill give a certain scientific evidence to the possible effect derivable from the implementation of a temporary artificial covering system on a worked-out landfill section: the lateral migration and concentration of gas emissions through an adjacent, active landfill section (as "Fano" Section "3").

\section{Acknowledgements}

The authors thank Dr. E. Imperatori, Dr. E. Sacchi, and university student A. Monaco for their contribution in carrying-out some monitoring campaigns.
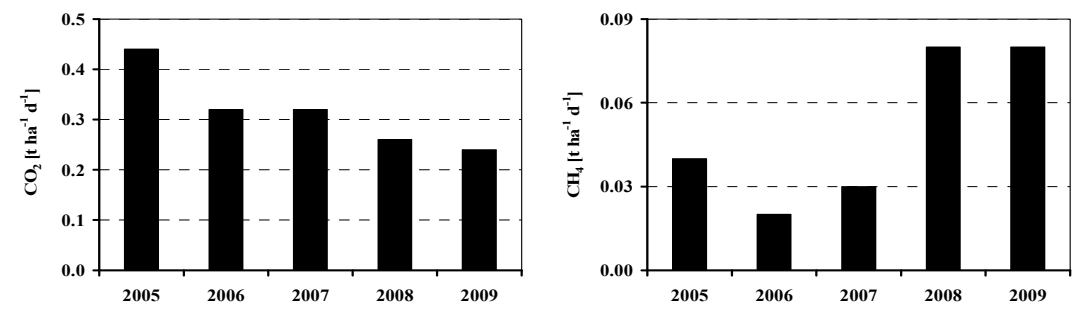

Figure 8: "Fano" case-study landfill: specific areal emissions for the whole landfill $\left[\mathrm{t} \mathrm{ha}^{-1} \mathrm{~d}^{-1}\right]$, as $\mathrm{CO}_{2}$ (left-hand side) and $\mathrm{CH}_{4}$ (right-hand side). 


\section{References}

[1] Directive 2008/98/EC on waste and repealing certain Directives, Official Journal of the European Union, L 312/3-30, 22.11.2008.

[2] Cossu, R., Lavagnolo, M.C. \& Raga, R., Role of landfilling in the modern strategies for solid waste management, Innovation in waste management, Environmental Series, Volume 23/b, C.I.P.A. Publisher, 2000.

[3] Huber-Humer, M., Gebert, J. \& Hilger, H., Biotic systems to mitigate landfill methane emissions, Waste Management \& Research, 26, pp. 33-46, 2008.

[4] Scheutz, C., Kjeldsen, P., Bogner, J.E., De Visscher, A., Gebert, J., Hilger, H.A., Huber-Humer, M. \& Spokas, K., Microbial methane oxidation processes and technologies for mitigation of landfill gas emissions, Waste Management \& Research, 27, pp. 405-455, 2009.

[5] Council Directive 1999/31/EC of 26 April 1999 on the landfill of waste, Official Journal of the European Communities, L 182/1-19, 16.07.1999.

[6] Italian Legislative Decree No. 36/2003 on the application of Directive 1999/31/EC on the landfill of waste, Ordinary Annex of the Official Italian Gazette No. 59, 12.03.2003 (in Italian).

[7] Cardellini, C., Chiodini, G., Frondini, F., Granieri, D., Lewicki, J. \& Peruzzi, L., Accumulation chamber measurements of methane fluxes: application to volcanic-geothermal areas and landfills, Applied Geochemistry, 18, pp. 45-54, 2003.

[8] Börjesson, G., Danielsson, A. \& Svensson, B.H., Methane fluxes from a Swedish landfill determined by geostatistical treatment of static chamber measurements, Environ. Sci. Technol., 34, pp. 4044-4050, 2000.

[9] Capaccioni, B., Lucci, P., Scartoni, P. \& Tatàno, F., Biogas flux measurements using the static, non-stationary accumulation chamber method: mapping, classification and selective characterisation of dispersions at Italian provincial scale, Proceedings of "Sardinia 2005", CISA, 2005.

[10] Capaccioni, B., Caramiello, C., Corigliano, G., de Rosa, S. \& Tatàno, F., Accumulation chamber measurements of biogas fluxes: experimental indications from four years application to a sanitary landfill in Marche Region (Italy), Proceedings of “Sardinia 2009”, CISA Publisher, 2009.

[11] Capaccioni, B., Caramiello, C., Corigliano, G., de Rosa, S. \& Tatàno, F., Monitoring and evaluation of landfill gas emission fluxes with the accumulation chamber method: multiyear experience at Fano sanitary landfill site, Proceedings of “Ecomondo 2009”, Maggioli Publisher, 2009.

[12] Spokas, K., Bogner, J., Chanton, J.P., Morcet, M., Aran, C., Graff, C., Moreau-Le Golvan, Y. \& Hebe, I., Methane mass balance at three landfill sites: What is the efficiency of capture by gas collection systems?, Waste Management, 26, pp. 516-525, 2006.

[13] Bogner, J., Meadows, M. \& Czepiel, P., Fluxes of methane between landfills and the atmosphere: natural and engineered controls, Soil Use \& Management, 13, pp. 268-277, 1997.

[14] Bahor, B., Van Brunt, M., Stovall, J. \& Blue, K., Integrated waste management as a climate change stabilisation wedge, Waste Management \& Research, 27, pp. 839-849, 2009. 